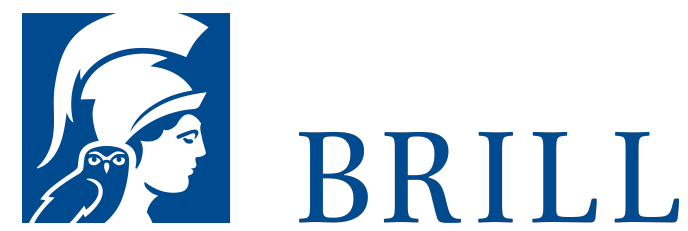

\title{
Das leibliche Widerfahrnis der Wahrnehmung
}

Eine Phänomenologie des Leib-Seele-Verhältnisses

Author: Jens Bonnemann

Bei allen Differenzen ist man sich in aktuellen und traditionellen philosophischen Debatten einig, die Wahrnehmung vorwiegend als sinnliche Erkenntnis zu untersuchen. Auf diese Weise gerät jedoch aus dem Blick, dass wahrzunehmen auch bedeutet, eine Einwirkung durch das Wahrgenommene zu erleiden, die als angenehm oder unangenehm erlebt wird. Das Wahrgenommene ist nicht nur z. B. > grün $<$ oder > rund <; es ist auch >lecker $<$, >stechend $<$ oder >ekelhaft<. Dieses Buch unternimmt zunächst eine phänomenologische Beschreibung des Wahrgenommenen, insofern es dem Wahrnehmenden widerfährt und wendet sich auf dieser Grundlage der Frage zu, was das leibliche Subjekt sein muss, wenn es unter der Wahrnehmung leiden oder sich an ihr erfreuen kann. Zum einen wird dafür argumentiert, die innerhalb der Leibphilosophie einschlägige Konzeption von Leib-sein und Körper-haben durch die dritte Dimension des >Vom-Körper-Gehabtwerdens` zu ergänzen. Zum anderen wird phänomenologisch aufgewiesen, inwiefern nicht nur die Welterfahrung leiblich, sondern umgekehrt auch die Selbst- und Leiberfahrung weltlich vermittelt ist.

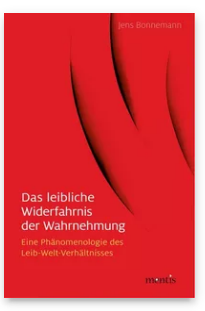

Pages: 407

Seiten

Language:

German

Subjects:

General, Philosophy

Publisher: Brill | mentis

E-Book (PDF)

Released online: 22 Dec 2015

ISBN: $978-3-$

95743-861-4

List price

Paperback

Publication date: 22 Dec 2015

ISBN: 978-395743-046-5

List price 
For more information see brill.com

Order information: Order online at brill.com +44330 333 0049 | customerservices@brill.com Submission information: brill.com/authors

Titles published by Brill | Fink, Brill | mentis or Brill | Schöningh: +49(o)715413279216| brill@brocom.de 